\title{
Approaches Looking Finite Elements Analysis of a Structural Model of Lid Stratified with Cellular Polymeric Core Specific to a Pressure Vessel
}

\author{
ION DURBACA ${ }^{1 *}$, RADU IATAN ${ }^{1}$, ADRIAN COSTIN DURBACA ${ }^{2}$, VASILE SACUIU ${ }^{1}$, MELANIA MITUCA CORLECIUC ${ }^{1}$, \\ CARMEN OTILIA RUSANESCU ${ }^{3}$ \\ IUniversity Politehnica of Bucharest, Faculty of Mechanical Engineering and Mechatronics, 313 Splaiul Independentei, 060042, \\ Bucharest, Romania \\ 2Richard Alan Engineering Ltd, Dewsbury (UK). \\ ${ }^{3}$ University Politehnica of Bucharest, Faculty of Biotechnical Systems Engineering, 313 Splaiul Independentei, 060042, Bucharest, \\ Romania.
}

\begin{abstract}
The paper treats Finite Element Analysis (FEA) specific to the mechanical behavior of a structural layer cap type with polymer cellular cores within a pressure vessel. The layered composite structure comprises two outer polymer shells (synthetic glass/ plexiglass) and cellular polymer core with triangular shaped cells. This analysis uses the Autodesk Inventor 2016 Professional 3D design and modeling software, in conjunction with the FEA analysis program, ANSYS 14.5 - Workbench, using the Mesh module. Mechanical behavior of the structural models specific to the four types of test caps, each having different cellular polymer core ( $A B S, P L A, P C$ and CF, 3 and $5 \mathrm{~mm}$ thickness), is revealed through the analysis of the state of stresses and deformations and correlating the FEA simulation results with experimental testing. Since the analysis leads to quasi-equivalent results under identical conditions of application until the fracture of the caps, it is found that such an FEA approach of the mechanical system components occupies an important place in the modern design process, being one of the ways of identifying the deformation fields and equivalent stresses in the analyzed composite structures.
\end{abstract}

Keywords: finite elements, multi-layered cellular, triangular cells.

Although the research of recent years has highlighted the attempt to harmonize mechanical testing with standards that define in detail such procedures and provide clear information on the dimensions of the specimens, the tolerances, the details of the materials that can be used for the tests, yet the comparative studies between the methods in the standards European Testing and American (ASTM) showed both similar results and differences between test results on the same materials [1]. Thus, although progress made over the past decades has had a positive impact on the evolution of composite materials testing, as well as the involvement of numerous companies in the field of composite research and development, there are limitations and uncertainties for some tests that required the development of new methods and analysis techniques [ 2 , $3,5,8]$.

As a relatively modern method, structural analysis using finite element method (FEA) is particularly versatile and efficient for analyzing the complex structural behavior of laminated composite structures, bringing to the forefront the possibility of applying it to various structures for which experimental testing could not use prototype configurations only through representative specimens [12-14, 22]. So, with all the cost and time constraints of prototype execution, FEA application is an innovative solution of great interest both economically and in terms of simulation time, and its results are most of the times dependent of the performance of the computing programs and the possibilities of their use [15].

The intense preoccupations in the international academic field, demonstrated by the large number of scientific papers published in the field and supported by the results obtained in various industrial applications [2325], reflect the practical importance of the finite element analysis of any composite layered structures [4].

In the literature, the cellular structure is referred to as the cellular core due to its positioning in a sandwich assembly that comprises two outer shells of the cellular core along with the joint addition of the core and the outer shells (example: sticking with thin-film and ultra-adherent film) $[6,7,10,11]$. This bonding joint causes the cellular

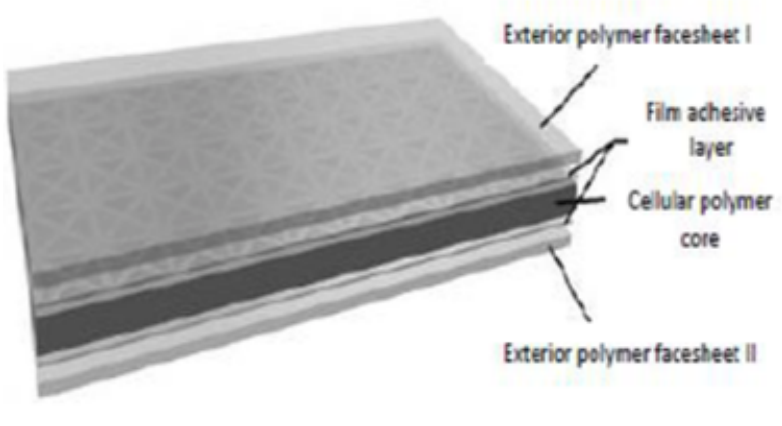

a)

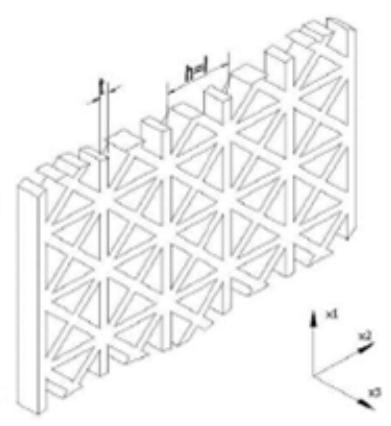

b)
Fig. 1. The main components of composite sandwich structures (a) and the geometry of the cell core $(b)$

*email: ion.durbaca@yahoo.com., Phone: +40723277389 
core and outer shells to behave as a continuous structure, thus transferring axial and transverse loads to and from the cellular core which provide sufficient rigidity to maintain equidistance between the outer envelopes [13, 14]. From the structural point of view (fig. 1), the main function of the cell core is to stabilize the outer sheaths to avoid buckling and deformation and to withstand the shear stresses along its thickness. The outer envelope supports, besides some of the local stresses and tension and compressive stresses, their main function being to provide the bending and shear stiffness of the sandwich assembly $[2,9]$.

Therefore, the use of modeling and simulation through the finite element analysis of mechanical system components occupies an important place in the modern design process and is one of the ways to identify deformation fields and equivalent stresses within the analyzed composite structures [2].

\section{Experimental part}

\section{Materials and methods}

The analysis of the experimental model of a pressurized container with a laminated lid and a cellular polymer core is based on the finite element method and involves knowledge of material behavior, geometric shape, type of contact with other parts, loads / stresses, functional behavior etc. $[2,3,9]$.

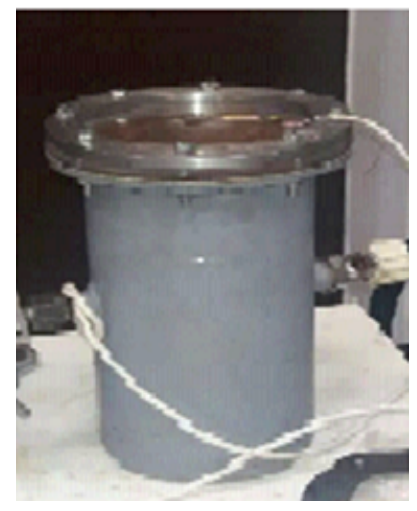

Fig. 2. Experimental model of pressure vessel with stratified cover [2] deformations and stresses states of the structure with finite elements and the visualization in various forms (lists, fields, diagrams, graphs) of the obtained sizes.

If the results of the FEA analysis show good consistency with the experimentally obtained results, further studies can be discarded in experimental parts, leading implicitly to direct economic effects $[2,3]$.

\section{Geometric definition of the model}

The 3D model was generated as a structural assembly consisting of the metal container (the cylindrical cover, the welded cap and the flange), the layered composite cover (made up of the top / bottom of synthetic glass Guttagliss Hobyglass / PMMA adhering to the core polymeric cell via the transparent film of Polymax / crystal express BISON) and metal screws.

Layer structure of layered composite sheets is shown in figure 3 , below $[2,3]$.

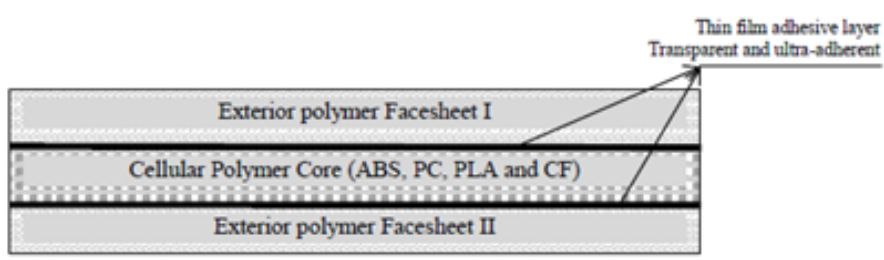

Fig. 3. Layer structure of a laminated composite sheet

The 3D model made in Autodesk Inventor 2016 Professional was exported in the neutral .step format, one of the most used file formats for transmitting 3D models (fig. 4), thanks to the major support received by introducing data representation requirements are contained in this file type, according to ISO 10303-21: 2016.

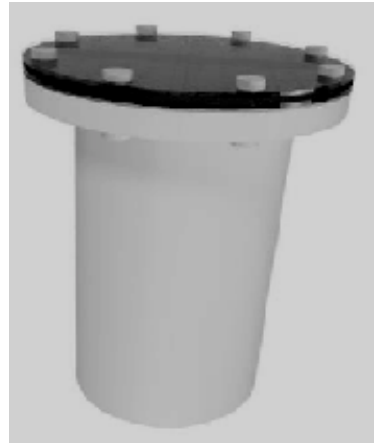

Fig. 4. The 3D model, made according to the execution drawing of the experimental model [2]

Since the model is symmetrical and can be represented by four equal parts, in order to simplify the pre / postprocessing time, only a quarter of the container was used in the analysis, having as axis the axis of revolution / rotation of the container. The same considerations have been discarded for modeling and simulating feed and drain fittings, placed on the sheath.

\section{Mesh model}

Meshing of the finite element model of the container was carried out using pre-processor ANSYS 14.5 Workbench, using Mesh module (fig. 5) [2].

At the same time, in addition to the type of element, the method of controlling the size of the finite elementfor sizing the body, was used. For the cylindrical shell, flange, and metal cap, a $4 \mathrm{~mm}$ element dimension was chosen, whereas in the case of metal screws, gasket, and cell core layered composite, a $2 \mathrm{~mm}$ element dimension was used. A total of 185580 knots and 45314 elements were finally obtained [2] 


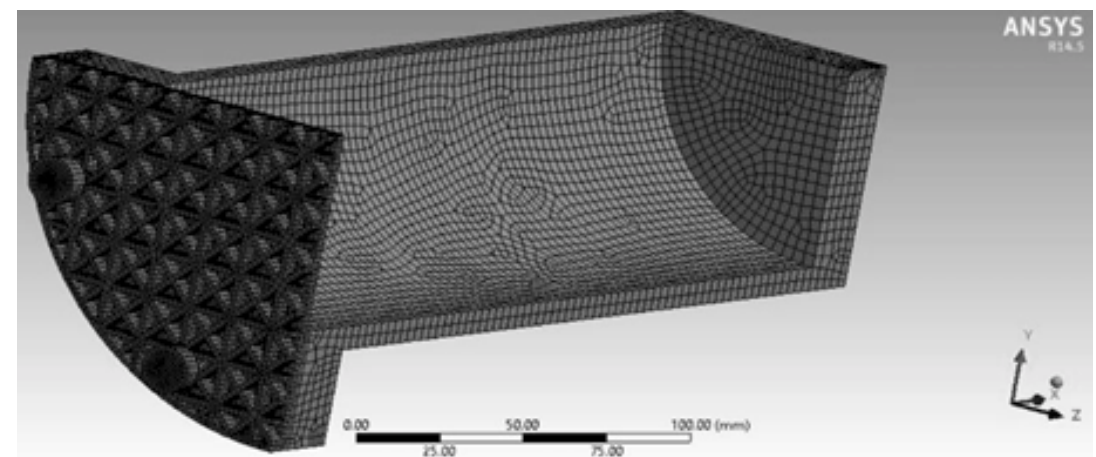

Fig. 5. ANSYS R14.5 (mesh) design of the pressure receptacle model with a cellular core layered lid (view of the core cell with the uppermost hidden face)

\section{Defining structural features}

Finite element analysis specific to this structural model requires knowledge of physical properties and mechanical behaviors for calculating the stiffness matrix of component elements $[2,15]$. These can be grouped in geometric properties and in material properties as shown in table 1 [2].

In the case of the MEF analysis of the pressure receptacle with a periodic cellular laminated composite cap, only 5 types of materials were considered for the composite cover. Thus, the upper faces are made of synthetic glass (plexiglass) and the core is made of ABS, PLA, CF or PC, having thicknesses of $3 \mathrm{~mm}$ and $5 \mathrm{~mm}$. In the case of cylindrical casing, flange, screws and cover, carbon steel was used as a material. Therefore, distinct simulations were made for each type of core material, in total 8 simulations. To highlight the mechanical behavior of the whole structure and to correlate the results of the MEF simulation with the experimental tests $[2,9,14]$, that took place until the composite cover was dismantled, it has been used the material release behaviors given by the material producers in combination with values in literature for properties for which no information is provided by producers.

\section{Defining boundary conditions for simulation of layered composite}

The limit conditions were specified in the static analysis module of the ANSYS program. Analysis with programs based on FEA requires specification of the limit conditions (restrictions, constraints) for the correct calculation of the results $[2,15]$. Their type is diversified according to the type of problem to be analyzed. For analyzing elastic

structures, the translation and rotation restrictions with known values [2].

Static analysis is used to determine the displacements, stresses, deformations and forces in its structure or components due to loads that do not induce significant effects of inertia or acceleration (shocks) $[2,3,14,15]$. Charging and response conditions are supposed to be stationary. The load type that can be applied in the static analysis includes applied external forces and pressures, inertial forces in the stationary state, such as gravity or rotational speed that require non-zero displacements, temperatures. A static analysis can be both linear and nonlinear. In the case presented in the paper, only static non-linear analysis was studied [2].

The fixation of the pattern takes place in the outer face of the metal cover, as it has been considered that this embedding has no effect on the results of the composite cover being analyzed and at the same time the pressure effect on it is negligible. At the same time, the symmetry of the model was considered, blocking the displacements of the faces in their perpendicular directions. The acceleration of gravity of $9.81 \mathrm{~m} / \mathrm{s}^{2}$ was also taken into consideration on the same axis of rotation / rotation of the container, having a direction perpendicular to its metal bottom (fig. 6) [2].

Due to the load mode of the real model, three calculation steps were considered for a total period of 1 second (neglecting the effect of the adhesive between the plates), namely:

$-(0 \div 0.25) \mathrm{s}$, bolt clamping is performed with a force of $5000 \mathrm{~N} / \mathrm{screw}$, value specific to the screw size used. The force of strain on a screw is the force that prolongs the screw and deforms the flanges;

\begin{tabular}{|l|c|c|c|c|c|}
\hline \multicolumn{1}{|c|}{ Feature } & PLA & $\begin{array}{c}\text { PLA + 40\% carbon } \\
\text { fiber }\end{array}$ & ABS & PC & PMMA \\
\hline \hline Density, $\rho\left[\mathrm{g} / \mathrm{cm}^{3}\right]$ & 1.25 & 1.29 & 1.1 & 1.2 & 1.18 \\
\hline Elastic modulus, $E[\mathrm{GPa}]$ & 2.5 & 2.2 & 2.2 & 1.96 & 2.7 \\
\hline Elongation [\%] & 6 & 2 & 2.6 & 4 & 3 \\
\hline Yield strength [MPa] & 40 & 48 & 42 & 50 & 50 \\
\hline Tensile strength [MPa] & 45 & 52 & 49 & 55 & 60 \\
\hline Shear modulus, G[GPa] & 0.92 & 0.81 & 0.81 & 0.72 & 0.99 \\
\hline Poisson's ratio, $v[-]$ & 0.36 & 0.36 & 0.35 & 0.37 & 0.37 \\
\hline
\end{tabular}

Table 1

PROPERTIES USED IN FEA ANALYSIS

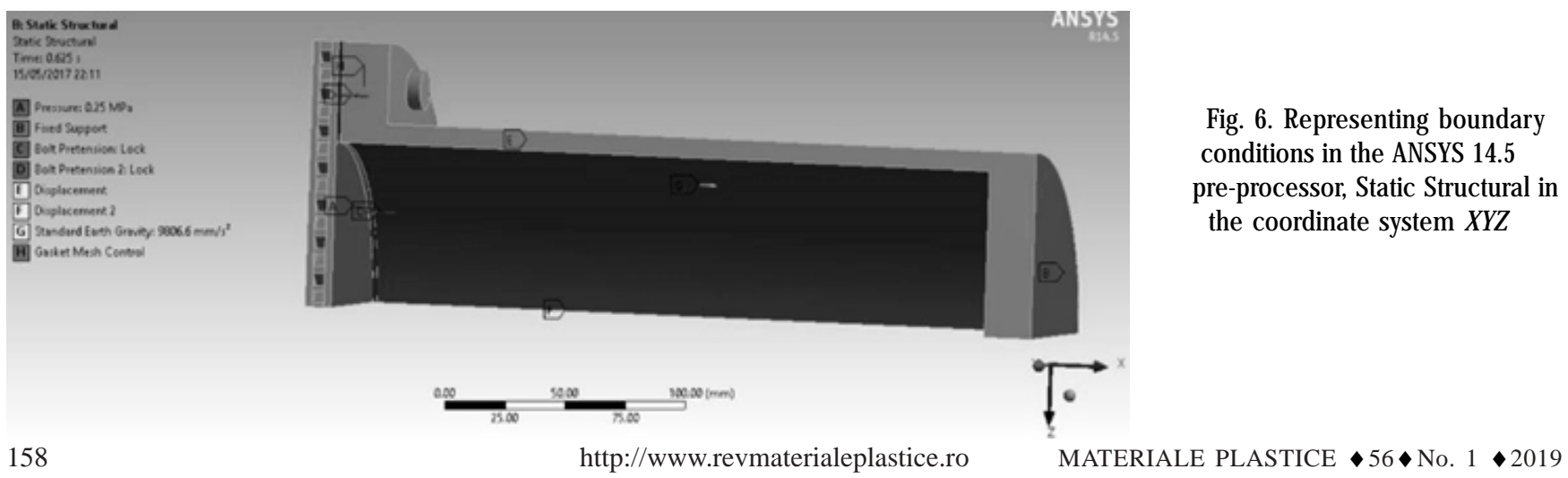


$-(0.25 \div 0.625) \mathrm{s}$, linear pressure rise from $0 \mathrm{MPa}$ to 0.25 MPa occurs;

$-(0.625 \div 1.0) \mathrm{s}$, a linear pressure drop of $0.25 \mathrm{MPa}$ to 0 $\mathrm{MPa}$ occurs.

\section{Results and discussions}

The post-processing program for results in ANSYS is a powerful and friendly program. Using interactive color graphics, it provides outstanding processing capabilities for the visualized results and finite element analysis. A drawing of the results of visual analysis can be obtained easily in a few seconds. Such an analysis would take many hours of work for an engineer to evaluate it by analytical methods [2, 3].

Using the program capabilities, the following views are possible: contour stresses, travel, temperatures, trace of deformed geometry; plotting history by time of different calculated sizes; solid sections; drawing hidden lines; drawing shadows from a light source; drawing boundary lines.

Thus, in the case of this analysis, the following aspects were pursued $[2,3]$ :

- values of the specific deformations corresponding to the areas measured by resistive tensometry;

- the values of the minimum and maximum deformations of the layered composite cover assembly;

- the maximum stress values for the evaluation of the mechanical behavior of the layered composite;

- maximum / minimum values and normal pressure distribution on the gasket surface.

In the case of the FEA analysis of the pressurized container with periodic cellular laminated composite cap, it was considered for the structure specific to the layered composite cover, 5 types of materials. Thus, the upper faces are made of synthetic glass (plexiglass) and the core is made of ABS, PLA, CF or PC, having thicknesses of $3 \mathrm{~mm}$ and $5 \mathrm{~mm}$. Different simulations have therefore been made for each type of core material, $3 \mathrm{~mm}$ thick and $5 \mathrm{~mm}$ in total, 8 simulations. In order to highlight the mechanical behavior of the entire structure and to correlate the results of the FEA simulation with the experimental tests [9], that took place until the composite cover was dismantled, it has been used the material release behaviors given by the material producers in combination with literature values [16-21], for properties for which no information is provided by manufacturers.

Output data for nodal points and finite elements could be analyzed, studied and compared in the three directions. The large amount of information prevented their presentation entirely in the paper, but only the obtained values, considered representative, were presented, which can also be compared with the experimental ones [2].

To compare the simulation results with the experimental results, a value / sample of instantaneous values was used for a 3D model in a predefined location. At the measuring points according to the distribution of the strain gauges on the experimental model, termed TER 0 , TER $1, \ldots$, TER 8 , they were positioned starting from the center of the composite cover, then distributed $90^{\circ}$ to one another towards the end of the cover (fig. 7) [2].

The analysis of the state of specific deformations and stresses was focused on the behavior of the layered composite model and less on the metallic model (container, flange, cover, screws) and gasket due to superior mechanical characteristics. However, their effect on the composite cap was considered. At the same time, prior to the commencement of the experiments, for the safety of the personnel and the testing equipment, preliminary resistance and design calculations were made on the components of the container.

For a better characterization of the cellular core layered composite cap, it was the distribution of the von Mises stresses for each component (fig. $8 \div$ fig. 11) [2].
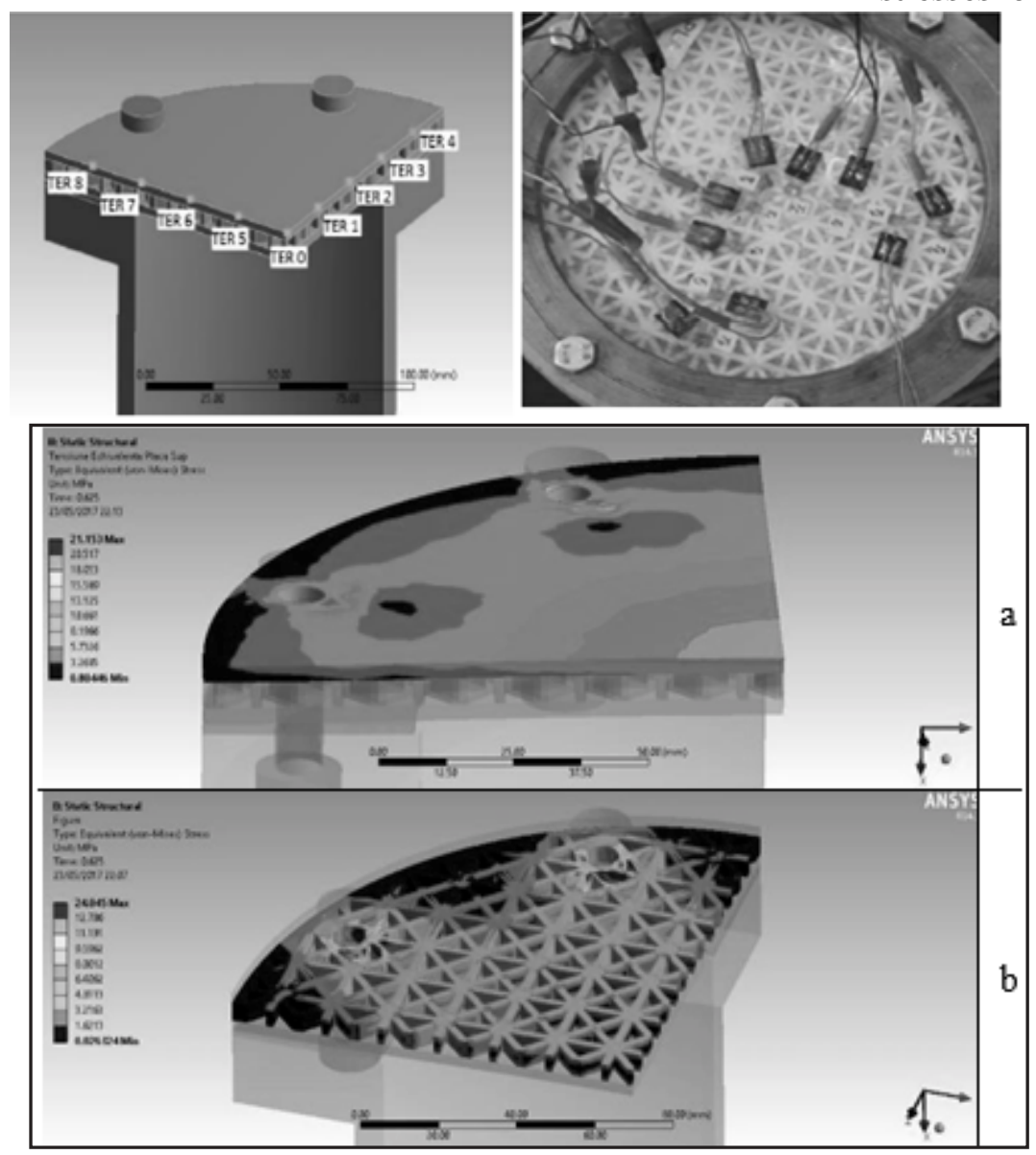

Fig.7. Positioning the measuring points on the 3D model of the composite cover (a),

according to their positioning on the experimental model $(b)$.

Fig. 8. Equivalent von Mises stress distribution in [2]: a)the top layer of the composite plate; b) core 


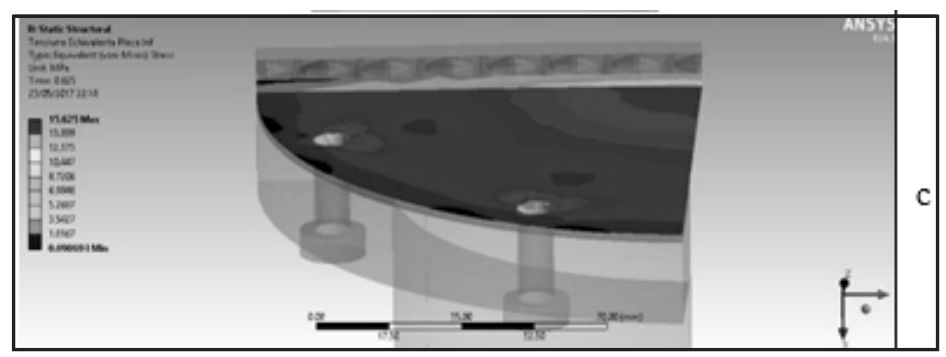

Analyzing the values and distribution of stresses in figure $8 \div$ figure 11 , the following observations were noted:

- maximum stresses values are similar in the four types of caps and have values of approximately $21 \div 25 \mathrm{MPa}$. These maximum values are located near the screw holes due to the pre-tightening of the bolts and the bending moment due to the internal pressure of the container relative to the screws;
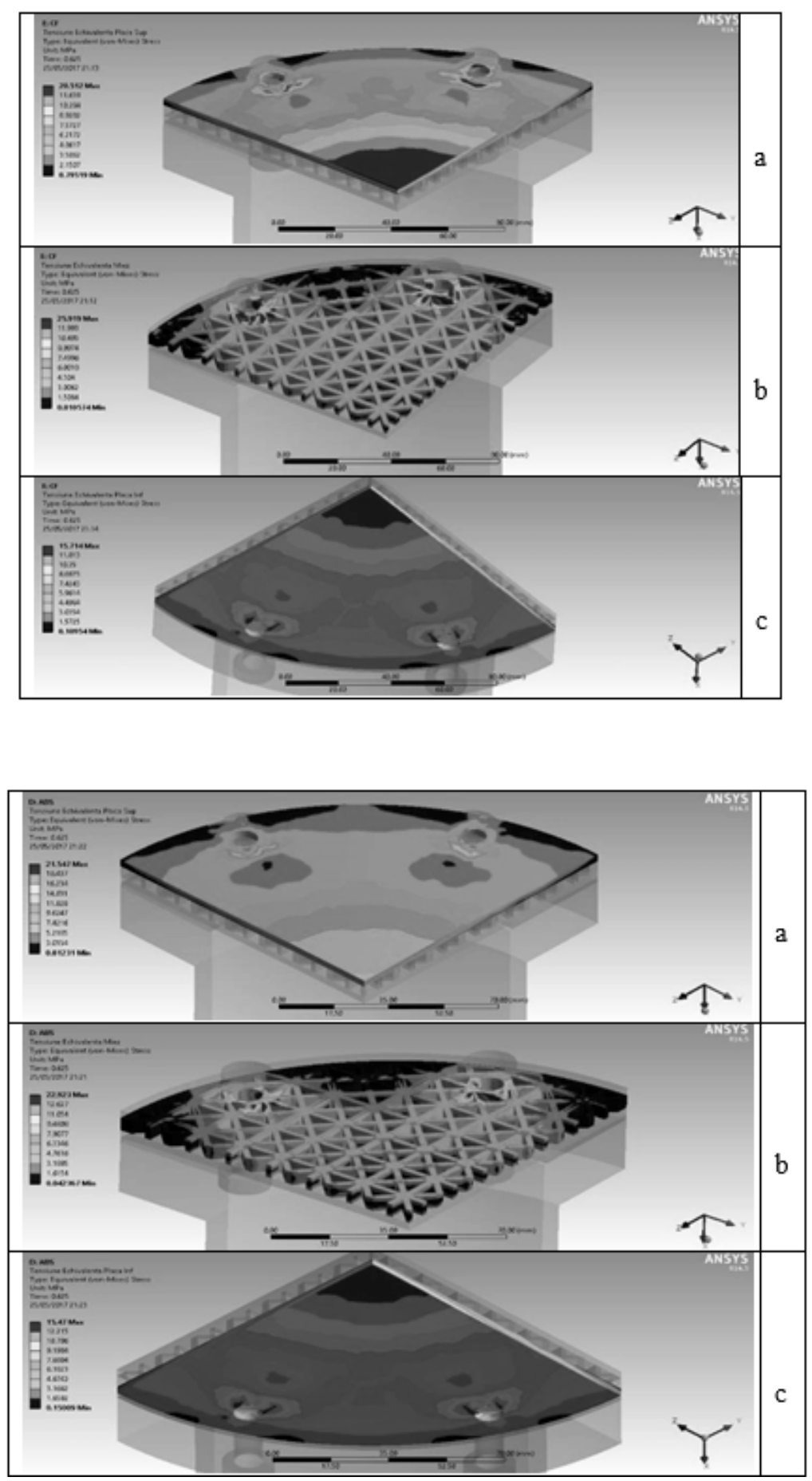

Fig. 8. Equivalent von Mises stress distribution in [2]:

c) lower layer for $5 \mathrm{~mm}$ thick cellular core cover made from PLA and acrylic facesheets

Fig. 9. Equivalent von Mises stress distribution in [2]: a) the top layer of the composite plate; b) core;

c) lower layer for $5 \mathrm{~mm}$ thick cellular core cover made from CF and acrylic facesheets

Fig. 10. Equivalent von Mises stress distribution in [2]: a)the top layer of the composite plate; b) core;

c) lower layer for $5 \mathrm{~mm}$ thick cellular core cover made from ABS and acrylic facesheets 


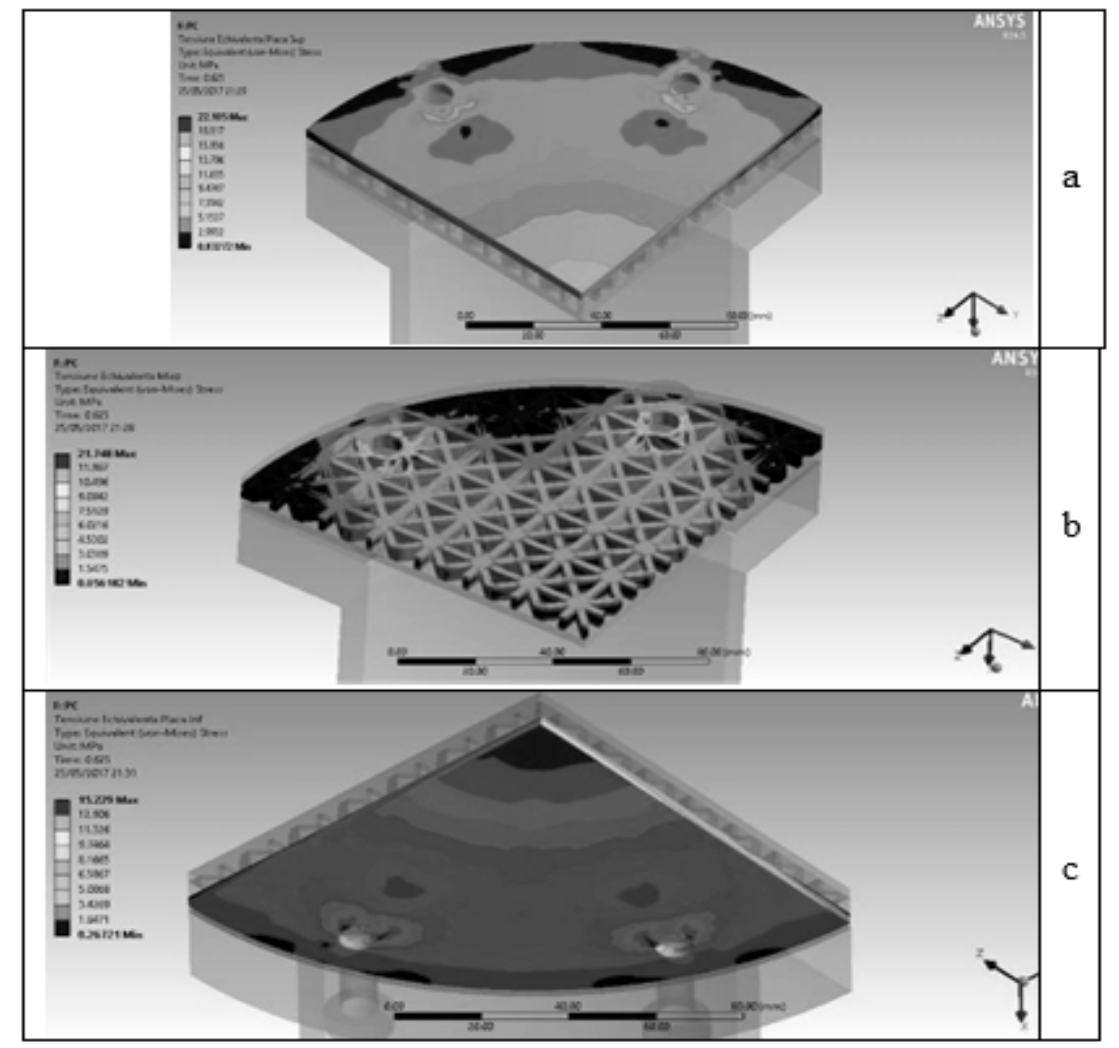

Fig. 11. Equivalent von Mises stress distribution in [2]: a)the top layer of the composite plate; b) core; c) lower layer for $5 \mathrm{~mm}$ thick cellular core cover made from PC and acrylic facesheets

\section{Conclusions}

Comparing the von Mises equivalent stress values obtained by simulation with those obtained experimentally, we found the following [2]:

- the existence of clear differences between the values of the experimental tensions and the numerical values in the case of the ABS core cap, differences which are mainly due to manufacturing errors;

- the equivalent stress values for plates made of PLA, $C F, A B S$ and $P M M A$ cores are similar (ranging from $0.5 \%$ to several tens of percent in certain measuring areas but having the same order of magnitude). Thus, there were small differences between these values, but also a uniform distribution of stresses: the minimum values tend to the outside of the lid, while the maximum values tend towards its interior. Some differences may be due to measurement errors, but also to the simplification and enforcement of limit conditions.

\section{References}

1. ADAMS, D.F., A Comparison of CEN and ASTM test methods for composite materials, Washington: U.S. Department of Transportation, Federal Aviation Administration, Office of Aviation Research, Washington, D.C. 20591, June 2004, p. 2-4.

2. DURBACA, A.C., Cercetari teoretice si experimentale privind evaluarea caracteristicilor fizico-mecanice ale placilor polimerice de tip sandwich cu miez compus din celule triunghiulare, Teza de Doctorat, Universitatea POLITEHNICA din Bucuresti, 2018/Theoretical and experimental researches on the evaluation of the physico mechanical characteristics of triangular cell composite sandwich plates, PhD Thesis, POLITEHNICA University of Bucharest, 2018.

3. ITU, C., Contributii privind imbunatatirea placilor circulare realizate din materiale compozite stratificate, Teza de Doctorat, Universitatea TRANSILVANIA din Brasov, 2014 / Contributions for Improvement of Circular Plates Made from Composite Layered Composites, PhD Thesis, TRANSILVANIA University of Brasov, 2014.
4. DURBACA, I., DURBACA, A.C.- Injection moulding simulation of polymer structures modeled with finite element, The Scientific Bulletin of Valahia University Materials and Mechanics, nr. 6 (year 9), 2011, p. $156-159$.

5. SYNGELLAKIS, S., Composites: Advances in Manufacture and Characterisation. Wessex, UK: Wessex Institute of Technology, UK, 2016, ISBN 978-1-78466-167-0, p. 93-108.

6. SCHEFFLER, M., COLOMBO, P., Cellular Ceramics: Structure, Manufacturing, Properties and Applications. s.l.: John Wiley \& Sons, 2016. ISBN: 978-3-52731-320-4, p. 3-16.

7. BLACK, S., Core Materials: Getting To The Core Of Composite Laminates, Composites Technology 9 (5), October 2003, p. 24-29.

8. DURBACA, I., POPA, N., VOICU, Gh., DURBACA, A.C., Theoretical and Experimental Approaches Specific to Monolayer Composite Plates Obtained from Urban and Industrial Recycled Plastic Wastes and Proteic Fibers, Mat. Plast., 52, no. 4, 2015, p. $464-469$

9. DURBACA, A.C., IATAN, R., DURBACA, I., DINITA, A., VASILESCU, $M$. Experimental Research on the Triangular Lattice Type Polymer Based Composites Structures for Sandwich Panels Construction, Mat. Plast. 54, no. 4, 2017, p. 639-644

10. ZENKERT, D., The Handbook of Sandwich Constructions, Engineering Materials Advisory Services (EMAS) Ltd., Cradley Heath, Chameleon Press Ltd, London, United Kingdom,1997, p. 442.

11. ZENKERT, D., Sandwich beam theory - an introduction, in: Ferreira, A.J.M. (Ed.), Advanced School on Sandwich Structures, Porto, Portugal, 2008, p. 9-10.

12. PENDLETON, R. L., Tutle, M. E., Manual of Experimental Methods for Mechanical Testing of Composites. s.l., SEM, 1989, p. 11-16, p. 1726.

13. PARSONS, M. W., PASCOE, K. J., Development of a Biaxial Fatigue Testing Rig. s.l., Journal of Strain Analysis, Vol. 10, Issue 1, 1975, p. 19.

14. CONSTANTIN, N., JIGA, G., HORHOIANU, N., HADAR, A., Cadru experimental pentru incercarea epruvetelor in regim de solicitare biaxiala, Bucuresti, Revista Constructia de masini, nr. 8-9, august septembrie 1995, p. 5-6 / Experimental framework for the testing of biaxially stressed specimens, Bucharest, Machine Building Review, no. 8-9, August-September 1995, p. 5-6. 
15. HADAR, A.,CONSTANTIN, N., JIGA, G., Element finit pentru analiza starilor locale de tensiuni din compozite stratificate unidirectionale, Revista Constructia de masini, Bucuresti, nr. special 1, 1998, p. 42-47, ISSN 0573-7419.

16. KUMAR, G.S., KUMAR, K., Surface roughness investigation and prediction models for polyjet 3D printed parts, Leiria, Portugal, High Value Manufacturing, Advanced Research in Virtual and Rapid Prototyping, Proceedings of the 6th International Conference on Advanced Research in Virtual and Rapid Prototyping, Volume 10, Issue 1,2015 , p. 23-34.

17.GIBSON, I., ROSEN, D., STUCKER, B., Additive Manufacturing Technologies: 3D Printing, Rapid Prototyping and Direct Digital Manufacturing, Springer Science and Business Media, New York, USA, 2015, Second Edition, p. 1-2, p. 122-124, p. 147, p. 161-165, p. 417-419. 18. GUO, N., LEU, C., Additive manufacturing: technology, applications and research needs. s.l., Frontiers of Mechanical Engineering, Volume 8, Issue 3, 2013, p. 215-243.

19.KRUTH, J.P., LEU, M.C., NAKAGAWA, T., Progress in Additive Manufacturing and Rapid Prototyping. s. I., CIRP Annals - Manufacturing Technology, Volume 47, Issue 2, 1998, p. 525-540.

20. SMITH, R., 7 Ways 3D Printing Is Already Disrupting Global Manufacturing, Forbes, 2015, [Interactiv][Citat: 12 Mai 2016] http:// www.forbes.com/sites/ricksmith/2015/06/29/7-ways-3d-printing-isalready-disrupting-global-manufacturing/\#1a8814d1158b.
21. ZUKAS, V., ZUKAS, J.A., An Introduction to 3D Printing, s.l., First Edition Design Pub, 2015, p. 6-11.

22. HERRANEN, H., PABUT, O., EERME, M., MAJAK, J., POHLAK, M., KERS, J., SAARNA, M., ALLIKAS, G., ARUNIIT, A., Design and Testing of Sandwich Structures with Different Core Materials, Materials Science (Medziagotyra), Vol. 18, No. 1, 2012, Lithuania, ISSN 1392-1320, 2012, p. $45-50$.

23.ENACHESCU, Georgiana, STEFANESCU, Mariana-Florentina, Modelling Heat Transfer Phenomenon for Smart Composite Materials, Mat. Plast., 53, no. 2, 2016, p.198-201

24.BERE, P., KROLCZYK, J.B., Determination of mechanical properties of carbon/epoxy plates by tensile stress test, International Conference Energy, Environment and Material Systems (EEMS 2017), sept. 13-15, 2017, Poland, ISSN: 2267-1242, W OS: 000426609200098.

25. HANCU, L., G. MARC, G., POPESCU, A., BERE, P., Proposal for a composite structure and graphic design for a parking barrier, 13th International Conference on Modern Technologies in Manufacturing (MTeM-AMaTUC), Cluj Napoca, ROMANIA, oct. 12-13, 2017, Volume: 137, Article Number: UNSP 08004, Published: 2017, DOI: 10.1051/ matecconf/201713708004, ISBN:978-2-7598-9027-9, ISSN: 2261-236X, WOS:000426604200080.

Manuscript received: 27.12 .2019 